\title{
Quantitative real-time PCR detection of Zika virus and evaluation with field-caught Mosquitoes
}

\author{
Oumar Faye ${ }^{1}$, Ousmane Faye ${ }^{1}$, Diawo Diallo², Mawlouth Diallo², Manfred Weidmann ${ }^{3}$ and Amadou Alpha Sall ${ }^{* *}$
}

\begin{abstract}
Background: Zika virus (ZIKV), a mosquito borne flavivirus is a pathogen affecting humans in Asia and Africa. ZIKV infection diagnosis relies on serology-which is challenging due to cross-reactions with other flaviviruses and/or absence or low titer of $\operatorname{lgM}$ and $\operatorname{lgG}$ antibodies at early phase of infection- virus isolation, which is labor intensive, time consuming and requires appropriate containment. Therefore, real-time RT-PCR (rRT-PCR) is an appealing option as a rapid, sensitive and specific method for detection of ZIKV in the early stage of infection. So far, only one rRT-PCR assay has been described in the context of the outbreak in Micronesia in 2007. In this study, we described a one step rRT-PCR for ZIKV which can detect a wider genetic diversity of ZIKV isolates from Asia and Africa.

Results: The NS5 protein coding regions of African ZIKV isolates were sequenced and aligned with representative flaviviruses sequences from GenBank to design primers and probe from conserved regions. The analytical sensitivity of the assay was evaluated to be 32 genome-equivalents and 0.05 plaque forming unit (pfu). The assay was shown to detect 37 ZIKV isolates covering a wide geographic in Africa and Asia over 36 years but none of the 31 other flaviviruses tested showing high analytical specificity. The rRT-PCR could be performed in less than 3 hours. This method was used successfully to detect ZIKV strains from field-caught mosquitoes.

Conclusion: We have developed a rapid, sensitive and specific rRT - PCR for detection of ZIKV. This assay is a useful tool for detection of ZIKV infection in regions where a number of other clinically indistinguishable arboviruses like dengue or chikungunya co-circulate. Further studies are needed to validate this assay in clinical positive samples collected during acute ZIKV infection.
\end{abstract}

\section{Background}

Zika virus (ZIKV) is an arbovirus (Flaviviridae family genus flavivirus [1] transmitted by mosquitoes. Its natural transmission cycle in Africa involves primarily Aedes species including Ae. furcifer, Ae. taylori and Ae. luteocephalus and Cercopithecus aethiops, Erythrocebus patas monkeys [2] while it is also transmitted by domestic mosquitoes Aedes (Ae.) aegypti, Ae. hensilli [3]. The survival of ZIKV in interepizootics is believed to depend on vertical transmission of the virus in Aedes [4].

Like all flaviviruses, ZIKV is a single-stranded RNA virus with a positive-polarity RNA genome of approximately $11 \mathrm{~kb}$. Both termini of the genomic contain sequences that do not encode viral proteins, known as the $5^{\prime}$ and the $3^{\prime}$ untranslated region. The encoded polyprotein is translated

\footnotetext{
* Correspondence: asall@pasteur.sn

${ }^{1}$ Unité des Arbovirus et virus de fièvres hémorragiques, Institut Pasteur Dakar, 36, Avenue Pasteur, BP 220 Dakar, Senegal

Full list of author information is available at the end of the article
}

and co- and posttranslationally processed by viral and cellular proteases into three structural (capsid [C], premembrane $[\mathrm{prM}]$ or membrane $[\mathrm{M}]$, and envelope $[\mathrm{E}]$ ) and seven nonstructural (NS1, NS2a, NS2b, NS3, NS4a, NS4b, and NS5) proteins. The NS5 protein is constituted by two distinct domains, an $\mathrm{N}$-terminal methyltransferase and a C-terminal RNA-dependent RNA polymerase that are required for capping and synthesis of the viral RNA genome, respectively [5-7].

ZIKV infection in humans symptoms ranges from asymptomatic to influenza like symptoms such as fever, headache, arthralgia, myalgia, malaise, anorexia, rash, asthenia, retro-orbital eye pain, oedema, lymphadenopathy, and diarrhoea [8-11]. The non-specific clinical presentation can be confused with most other arboviruses particularly dengue and chikungunya virus infection.

ZIKV, an emerging neglected virus, was first documented in 1947 when it was isolated from a sentinel rhesus monkey stationed on a tree platform in the Zika forest, Uganda [12].

\section{Biomed Central}


Since then, epizootics and small epidemics have occurred in Africa and Asia [13]. In Africa, the first human isolated has been described during an outbreak of jaundice in eastern Nigeria by MacNamara, 1954 [13]. Then, serological and entomological Zika infection were reported in different area in Africa (Burkina Faso, Ivory Cost, Egypt, Central African Republic, Mozambic, Nigeria, Uganda, Central African Republic and Senegal) [2,9,14-19]. Between 1968 and 2002, 606 strains including 10 human ZIKV strains were isolated in Central and West Africa countries and reported by the WHO Collaborating Center for Arbovirus and Viral Hemorrhagic Fever of Pasteur Institute in Dakar [20]. In 2007, the outbreak in Yap (Micronesia) became the largest outbreak of ZIKV ever reported [21]. In Senegal, the entomological and virological surveillance program of arboviruses since 1972 showed an enzootic circulation of ZIKV [20]. In 2008, a probable non vector transmission of ZIKV were reported when two American scientists contracted the virus while working in Kedougou, South-Eastern Senegal. The transmission of ZIKV to the wife of one of the scientists who had no history travel in the virus endemic area supports sexual transmission of ZIKV in this case [22].

Currently diagnosis of ZIKV infection is based on detection of specific antibodies or virus isolation from animals or mosquitoes which are time consuming $[13,23]$. Standard RT-PCR and quantitative RT-PCR provide a rapid, specific and sensitive method for ZIKV early detection $[21,22]$. However, real-time PCR, in contrast to conventional assays, has many advantages, including rapidity, quantitative measurement, low contamination rate and easy standardization. To date, one rRT-PCR assay focusing on the detection of Micronesian ZIKV strains [21] is available but it does not cover the genetic diversity and geographic distribution of ZIKV. In this study, we developed a one step rRT-PCR assay capable to detect ZIKV strains circulating in Africa and Asia.

\section{Material and methods Viruses}

Viral strains used were provided by WHO Collaborating Center for arboviruses and viral hemorrhagic fever (CRORA) at the Institut Pasteur de Dakar. ZIKV and other flaviviruses strains isolated from mosquitoes and non-human vertebrates used in this study are described in Tables 1 and 2. Viral stocks were prepared by inoculating viral strains into AP 61 monolayer continuous cell lines in Leibovitz 15 (L-15) growth medium (GibcoBRL, Grand Island, NY, USA) supplemented with 5\% foetal bovine serum (FBS) (GibcoBRL, Grand Island, NY, USA), $10 \%$ tryptose phosphate, penicillin-streptomycin and fungizone (Sigma, Gmbh, Germany). After 7 days of propagation, viral infection was tested by an indirect immunofluorescence assay (IFA) using specific hyperimmune mouse ascitic fluids as previously described
[23] and supernatants from infected cells were collected as stocks for virus RNA isolation. ZIKV stocks were used for sequencing and evaluation of the sensitivity of the rRT-PCR assay. Other flaviviruses were used to evaluate the specificity of the assay.

\section{Titration of viral stocks}

Viral stocks were titrated on Vero cells (African Green Monkey Kidney) supplemented with 10\% fetal bovine serum (FBS) as well as penicillin-streptomycin (1\%) and fungizone $(0,05 \%)$. Viral suspension stock were serially 10 -fold diluted in L-15 medium with 10\% FBS. Two hundred microliters were inoculated on Vero cell monolayers in the wells of a 24-well plate. After $4 \mathrm{~h}$ of virus adsorption at $37^{\circ} \mathrm{C}$, cells were overlaid with $3,2 \%$ of carboxymethylcellulose-L-15 medium containing 10\% FBS. After incubation at $37^{\circ} \mathrm{C}$ for 7 days, cells were stained with $1 \%$ black amido, dried at room temperature and the plaques were counted.

\section{Primer and probe design}

The NS5 sequences of ZIKV were chosen as target for the primers. ZIKV strains from Africa sequenced and desposited at Genbank (accession number, KF38304KF383114), strain from Malaysia (NC_012532) and the strain related to Micronesian outbreak in 2007 (EU545988) were aligned using the Clustal W program [24]. A stretch of nucleotides conserved in the strains was identified and the primers and a short LNA probe sequence (16 nt) was designed using the Primers Express software and the LNA probe design window at http://lna-tm.com/ [25]. The probe contained the fluorescent reporter dye 6-carboxyfluorescein (FAM) at the $5^{\prime}$-end and the fluorescent quencher dye 6-carboxytetramethylrhodamin (TAMRA) at the 3'-end. The primers and probe sequences and characteristics are shown in Table 3.

\section{Generation of RNA standard for the rRT-PCR}

An in vitro transcribed RNA of the NS5 gene of ZIKV strain ArD165531, was used to determine the detection limit of the assay. A size of $1083 \mathrm{bp}$ of the NS5 region was amplified with the primers FD3/FU1 [1] and the product was purified using the QIAquick gel extraction kit (Qiagen $\mathrm{GmbH}$, Heiden, Germany) and ligated to the pGEM-T vector (Promega, Madison, USA). The recombinant plasmid was used to transform E. coli X-Blue 1 strain (Invitrogen, Carlsbad, USA). The orientation of the insert DNA was confirmed by sequencing. The insert was amplified using the primers M13R/M13F and then purified using the QIAquick gel extraction kit. In vitro transcription and quantification of transcribed RNA was performed as previously described [26] with a slight modification consisting of DNA digestion using the DNAfree kit (Ambion, Austin, Texas, USA) instead of DNASE digestion and TRIZOL purification. The 
Table 1 Zika strains used in this study

\begin{tabular}{|c|c|c|c|}
\hline Reference & Hosts & Countries & Year of isolation \\
\hline $\operatorname{ArD} 7117$ & Aedes luteocephalus & Senegal & 1968 \\
\hline ArD 9957 & Aedes furcifer & Senegal & 1969 \\
\hline ArD30101 & Aedes luteocephalus & Senegal & 1979 \\
\hline ArD 30156 & Aedes furcifer & Senegal & 1979 \\
\hline AnD 30332 & Cercopithecus aethiops & Senegal & 1979 \\
\hline HD 78788 & Humain & Senegal & 1991 \\
\hline ArD 127707 & Aedes furcifer & Senegal & 1997 \\
\hline ArD 127710 & Aedes taylori & Senegal & 1997 \\
\hline ArD 127984 & Aedes furcifer & Senegal & 1997 \\
\hline ArD 127987 & Aedes luteocephalus & Senegal & 1997 \\
\hline ArD 127988 & Aedes furcifer & Senegal & 1997 \\
\hline ArD 127994 & Aedes taylori & Senegal & 1997 \\
\hline ArD 128000 & Aedes luteocephalus & Senegal & 1997 \\
\hline ArD 132912 & Aedes dalzieli & Senegal & 1998 \\
\hline ArD 132915 & Aedes dalzieli & Senegal & 1998 \\
\hline ArD 141170 & Aedes dalzieli & Senegal & 2000 \\
\hline ArD 142623 & Anopheles coustani & Senegal & 2000 \\
\hline ArD 149917 & Aedes dalzieli & Senegal & 2001 \\
\hline ArD 149810 & Aedes dalzieli & Senegal & 2001 \\
\hline ArD 149938 & Aedes dalzieli & Senegal & 2001 \\
\hline ArD 157995 & Aedes dalzieli & Senegal & 2001 \\
\hline ArD 158084 & Aedes dalzieli & Senegal & 2001 \\
\hline ArD 165522 & Aedes vittatus & Senegal & 2002 \\
\hline ArD 165531 & Aedes dalzieli & Senegal & 2002 \\
\hline ArA 1465 & Aedes africanus & Côte d'lvoire & 1980 \\
\hline ArA 27101 & Aedes opok & Côte d'Ivoire & 1990 \\
\hline ArA 27290 & Aedes opok & Côte d'Ivoire & 1990 \\
\hline ArA 27106 & Aedes luteocephalus & Côte d'Ivoire & 1990 \\
\hline ArA 27096 & Aedes africanus & Côte d'Ivoire & 1990 \\
\hline ArA 27407 & Aedes africanus & Côte d'Ivoire & 1990 \\
\hline ArA 27443 & Muci graham & Côte d'Ivoire & 1990 \\
\hline ArA 506/96 & Aedes vittatus & Côte d'Ivoire & 1996 \\
\hline ArA 975-99 & Aedes aegypti & Côte d'Ivoire & 1999 \\
\hline ArA 982-99 & Aedes vittatus & Côte d'Ivoire & 1999 \\
\hline ArA 986-99 & Aedes furcifer & Côte d'Ivoire & 1999 \\
\hline ArA 2718 & Aedes luteocephalus & Burkina Faso & 1981 \\
\hline ArB 1362 & Aedes africanus & Republic Center Africa & 1968 \\
\hline P6-740 & Aedes aegypti & Malaysia & 1966 \\
\hline
\end{tabular}

RNA quantification is performed with the fluorescence dye RiboGreen (Invitrogen, Eugene, Oregon, USA) which specifically binds to single strand RNA. The analysis is performed in a 96-well plate in the ABI-PRISM 7500 which is used as a fluorimeter. Quantification was performed in comparison to a RNA-standard of $20 \mathrm{ng} / \mathrm{ml}-1000 \mathrm{ng} / \mathrm{ml}$ RNA supplied with the kit and a standard curve was established. The copy of RNA (molecules/ $\mu \mathrm{l}$ ) was calculated as follows: $\mathrm{C} \times$ $\mathrm{A} / \mathrm{L}$ where $\mathrm{C}$ represents the concentration of RNA $(\mathrm{g} / \mathrm{mL})$ assessed by OD measurement, $\mathrm{A}$ is the Avogadro number $\left(6.023 \times 10^{23}\right)$, and $\mathrm{L}$ is the length of the synthetic RNA (nucledotide) and 330 is an 
Table 2 Flavivirus strains used in this study

\begin{tabular}{|c|c|c|c|c|}
\hline Flavivirus species & Reference & Hosts & Countries & Year of isolation \\
\hline Dengue 1 & ArA 15120 & Aedes aegypti & Côte d'Ivoire & 1985 \\
\hline \multirow[t]{9}{*}{ Dengue 2} & ArD 63334 & Aedes furcifer & Senegal & 1989 \\
\hline & ArA 6894 & Aedes aegypti & Burkina Faso & 1986 \\
\hline & ArA 29982 & Aedes lutoecephalus & Côte d'Ivoire & 1992 \\
\hline & ArD 140875 & Aedes furcifer & Senegal & 1999 \\
\hline & ArD 140884 & Aedes lutoecephalus & Senegal & 1999 \\
\hline & ArD 141069 & Aedes furcifer & Senegal & 1999 \\
\hline & ArD 141070 & Aedes lutoecephalus & Senegal & 1999 \\
\hline & ArD 141073 & Aedes taylori & Senegal & 1999 \\
\hline & ArD 142774 & Aedes fircifer & Senegal & 1999 \\
\hline Dengue 4 & HD 38549 & Human & Senegal & 1983 \\
\hline \multirow[t]{4}{*}{ Yellow Fever } & ArA 408/78 & Aedes luteocephalus & Côte d'Ivoire & 1978 \\
\hline & HA 016/97 & Human & Liberia & 1997 \\
\hline & ArD 149213 & Aedes lutoecephalus & Senegal & 2000 \\
\hline & ArD 149214 & Aedes furcifer & Senegal & 2000 \\
\hline \multirow[t]{2}{*}{ West Nile } & AF260968 & Human & Egypt & 1951 \\
\hline & M12294 & Human & Uganda & 1937 \\
\hline Usutu & ArD 130317 & Culex perfuscus & Senegal & 1998 \\
\hline Ss. Usutu & ArB 1803/69 & Culex perfuscus & Central African Republic & 1969 \\
\hline Bagaza & ArB 209 & Culex sp & Central African Republic & 1966 \\
\hline Bouboui & ArB 490 & Anopheles paludis & Central African Republic & 1967 \\
\hline Dakar Bat & AnD 249 & Scotiphilus sp & Senegal & 1962 \\
\hline Kedougou & ArD 14701 & Aedes minutus & Senegal & 1972 \\
\hline Koutango & AnD 5443 & Tatera kempi & Senegal & 1968 \\
\hline Ntaya & ArB 472 & Culex sp & Central African Republic & 1967 \\
\hline Uganda S & ArD 109325 & Ades furcifer & Senegal & 1994 \\
\hline Saboya & AnD 4600 & Tatera kempi & Senegal & 1968 \\
\hline Sepik & MK 7148 & Mansonia septempunctata & New Guinea & 1966 \\
\hline Spondweni & SA Ar 94 & Mansonia uniformis & South African Republic & 1955 \\
\hline Wesselsbron & ArB 4177 & Rhipicephalus muhsamae a & Central African Republic & 1982 \\
\hline Yaounde & $\operatorname{ArY} 276 / 68$ & Culex nebulosus & Cameroon & 1968 \\
\hline
\end{tabular}

approximation of the molecular weight of a nucleotide $(\mathrm{g} / \mathrm{mol})$.

\section{Analytical sensitivity of the assay}

The titer of ZIKV stocks were determined and 10-fold dilutions of the stock were used to study the sensitivity of the assay in a synthetic normal human plasma (Acrometrix, Benicia, CA), used in absence of naturally human infected ZIKV sample and Leibovitz 15 (L-15) growth medium (GibcoBRL, Grand Island, NY, USA), used as supernatants of infected AP61 cells with ZIKV.

\section{Viral RNA extraction}

RNA was extracted from ZIKV stocks using the QIAamp RNA Viral Kit (Qiagen GmbH, Heiden, Germany) according to the manufacturer's recommendations. Briefly, $100 \mathrm{ml}$ of culture supernatants were mixed with AVLCarrier RNA buffer. After $10 \mathrm{~min}$ incubation at room temperature, $400 \mathrm{ml}$ of ethanol was added and samples were transferred into a column containing silica and centrifuged at $8000 \mathrm{~g}$ for $1 \mathrm{~min}$. The RNA was washed twice with buffer AW1 and AW2, respectively. RNA was eluted in $50 \mu \mathrm{l}$ of TE buffer and stored at $-80^{\circ} \mathrm{C}$ until use.

\section{One-step real-time rRT-PCR}

RNA was amplified by real-time RT-PCR in an ABI Prism 7500 SDS Real-Time cycler (Applied Biosystems, Foster City, USA). The Quantitect One-Step RT-PCR kit (Qiagen, Hilden, Germany) was used with a $25 \mu \mathrm{l}$ reaction mixture under the following conditions: $0.25 \mu \mathrm{l}$ of 
Table 3 Nucleotide sequences of primers and probe used in the qRT-PCR assay

\begin{tabular}{lll}
\hline & Sequence $\mathbf{5}^{\prime} \mathbf{-} \mathbf{3}^{\prime}$ & Nucleotide position \\
\hline Probe & FAM-CTYAGACCAGCTGAAR-BBQ & $9304-9320$ \\
$\begin{array}{l}\text { Forward } \\
\text { primer }\end{array}$ & AARTACACATACCARAACAAAGTG GT & $9271-9297$ \\
$\begin{array}{l}\text { Reverse } \\
\text { primer }\end{array}$ & TCCRCTCCCYCTYTGGTCTTG & $9352-9373$ \\
\hline
\end{tabular}

FAM, 6-carboxyfluorescein; $B B Q$, Black Berry Quencher. $\mathrm{Y}=\mathrm{T}$ or $\mathrm{C}, \mathrm{R}=\mathrm{A}$ or $\mathrm{G}$.

kit enzyme mixture (including reverse transcriptase $\mathrm{RT}$ and Taq polymerase), $10 \mu \mathrm{l}$ of $2 \times$ Quantitect RT-PCR buffer, $1.25 \mu \mathrm{l}$ of $10 \mu \mathrm{M}$ of each primer, $0.5 \mu \mathrm{l}$ of $10 \mu \mathrm{M}$ of probe at $10 \mu \mathrm{M}, 6.8 \mu \mathrm{l}$ of DNA RNA free water (Mol Bio grade, Hamburg, Germany) and $5 \mu \mathrm{l}$ of the extracted sample. Each amplification run contained one negative and one positive control. The negative control consisted of blank reagent and water. For the positive control, nucleic acid extracted from virus stocks was used. The following thermal profile was used a single cycle of reverse transcription for $10 \mathrm{~min}$ at $50^{\circ} \mathrm{C}, 15 \mathrm{~min}$ at $95^{\circ} \mathrm{C}$ for reverse transcriptase inactivation and DNA polymerase activation followed by 40 amplification cycles of $15 \mathrm{sec}$ at $95^{\circ} \mathrm{C}$ and $1 \mathrm{~min} 60^{\circ} \mathrm{C}$ (annealing-extension step). The data were analyzed using the SDS software from Applied Biosystems.

\section{Field-caught mosquitoes}

Mosquitoes samples were collected during a routine surveillance for arbovirus in Kedougou, Southeastern Senegal from May to December 2011 as described previously [27] and pooled by species into groups of up 50 individuals. Monospecific mosquito pools were homogenized in $2.5 \mathrm{ml}$ of L-15 medium containing $20 \%$ fetal bovine serum (FBS) and centrifuged for $20 \mathrm{~min}$ at $10,000 \times \mathrm{g}$ at $4^{\circ} \mathrm{C}$. For the homogenate, $1 \mathrm{ml}$ of the supernatant was inoculated into Aedes pseudoscutellaris as described previously [23]. Cells were incubated at $28^{\circ} \mathrm{C}$. Within 10 days, slides were prepared for IFA against 7 pools of immune ascitic fluids specific for most of the African mosquito-borne arboviruses.
RNA was also extracted from supernatant of mosquitoes pools as described above and used for the ZIKV rRT-PCR assay. The mosquitoes pools were also screened for dengue an yellow fever using primers and probes described previously $[28,29]$.

\section{Results \\ Design and evaluation of primers and probes}

An alignment of the NS5 sequences of 13 African and 1 Asian (Malaysia) ZIKV strains identified a highly conserved region of 102 nucleotides (nt) and highly divergent from other flaviviruses. A reverse primer (nt 9352 -TCCRCTCC CYCTYTGGTCTTG-9373), a forward primer (nt 9271AARTACACATACCARAACAAAGTG GT-9297) and a 16 nt LNA-probe (nt 9304-FAM-CTYAGACCAGCTGAAR -BBQ -9320) were designed (Figure 1) (Table 3).

\section{Sensitivity and specificity of the rRT-PCR assay}

The assay detected the RNA of all 37 ZIKV strains (Table 1). The detection limit of the assay was evaluated using a quantitative RNA standard and a pfu-dilution series. To standardize the assay, serial dilutions of transcribed ZIKV RNA were tested by the real time PCR developed (Table 4). Three assays using transcript RNA prepared on different days were used to plot a standard curve (Figure 2A).

The detection was linear over $7 \log _{10}$ steps from $3,2 \times$ $10^{9}$ (Ct 12.15) to $3,2 \times 10^{2}$ molecules detected (Ct 34.79) and the regression coefficient $\left(R^{2}=0.9987\right)$ indicates that the assay is highly reproducible (Figure 2A). Intra-assay and interassay coefficient variation $(\mathrm{CV})$ of the mean $\mathrm{Ct}$ values ranged from $1.19-1.61 \%$ and $1.23-2.72 \%$ respectively when using synthetic RNA. The lowest detection limit of the rRT-PCR assay was also evaluated using ten-fold dilutions of a ZIKV stocks ranging from $5 \times 10^{4}$ to $5 \times 10^{-6} \mathrm{PFU} / \mathrm{ml}$ in L15 medium or synthetic normal human plasma. The result showed that the detection limit of the established rRTPCR assay was $0.05 \mathrm{pfu} /$ reaction in L15 medium and normal human plasma. The Ct values obtained were highly correlated $\left(R^{2}=0.9984\right)$ and ranged from 25.60 to 36.24

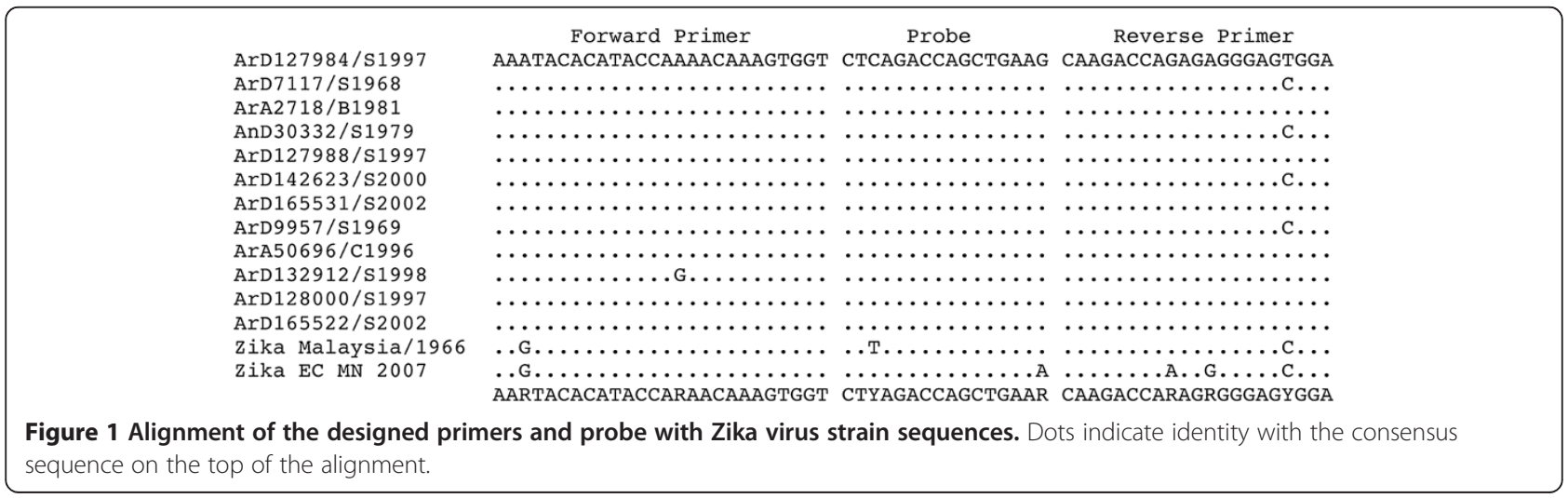




Table 4 Detection limit of the qRT-PCR assay for Zika
virus
\begin{tabular}{llll}
\hline Synthetic RNA / $\mathbf{l l}$ & $\mathbf{n b}$ positive/ nb tested & $\mathbf{C t}$ & Percentage \\
\hline $3,2 \times 10^{9}$ & $3 / 3$ & $12.15 \pm 0.15$ & 100 \\
$3,2 \times 10^{8}$ & $3 / 3$ & $15.76 \pm 0.21$ & 100 \\
$3,2 \times 10^{7}$ & $3 / 3$ & $19.32 \pm 0.25$ & 100 \\
$3,2 \times 10^{6}$ & $3 / 3$ & $22.62 \pm 0.27$ & 100 \\
$3,2 \times 10^{5}$ & $3 / 3$ & $25.28 \pm 0.31$ & 100 \\
$3,2 \times 10^{4}$ & $3 / 3$ & $28.50 \pm 0.46$ & 100 \\
$3,2 \times 10^{3}$ & $3 / 3$ & $31.77 \pm 0.39$ & 100 \\
$3,2 \times 10^{2}$ & $3 / 3$ & $34.79 \pm 0.43$ & 100 \\
$3,2 \times 10^{1}$ & $0 / 3$ & $n e g$ & 0 \\
$3,2 \times 10^{0}$ & $0 / 3$ & neg & 0 \\
\hline & & &
\end{tabular}

(Table 5, Figure 2B). The Cts across the quantitative range showed a standard deviation ranging from 1.13 to $1.61 \mathrm{Ct}$. The RNA of 37 ZIKV strains and 31 flavivirus strains (Table 2), was tested and no cross detection was observed indicating a high specificity of the assay.

\section{Evaluation of the real-time RT-PCR assay analyzing mosquito and serum samples}

Overall a total of 1969 pools of mosquitoes collected at different sites in Kedougou between May to December 2011 were tested using the ZIKV rRT-PCR assay. ZIKV was detected in 31 mosquito pools out of 1969 from Aedes and Mansonia genus. A total of 15 out of 31 (49\%) mosquito pools were found positive by rRT-PCR, while 7 (22\%) mosquitoes pools were positive by virus isolation and 9 (29\%) were positive by both tests, with $\mathrm{Ct}$ values ranged between 20 to 35 . The rRT-PCR method was significantly more sensitive than virus isolation (Khi2 test, $\mathrm{p}=0.0371$ ). No mosquito pool was found positive for dengue and yellow fever virus. Aedes africanus, Aedes furcifer and Aedes luteocephalus species were the most infected vectors with $16 \%$ positive $(5 / 31$ strains) each. The result showed that $87 \%$ (27/31 strains) of the positive pools were collected in June and
September to December. NS5 region of positive mosquito pools for ZIKV NS5 were amplified and sequenced using primers FD3/FU1 described previously [1] A blast alignment of the ZIKV NS5 sequences showed 97 to $100 \%$ similarity with ZIKV strain ArD41519 (accession number HQ234501) isolated in Kedougou, SouthEastern Senegal, in 1984.

\section{Discussion}

In West Africa, ZIKV epizootics are regularly detected [20] but few human cases are reported. Underreporting might be due to the circulation of other arboviruses which cause similar clinical features as ZIKV infection. Detection of ZIKV so far is based and virological methods, which are time consuming. A previously developed RT-PCR was adapted for real time PCR detection of ZIKV in samples from human cases during the 2007 Micronesian outbreak [21].

In this study, we have developed a new sensitive and specific one step rRT-PCR for detection of ZIKV in serum and cell culture supernatants using a Taqman probe containing locked nucleotides, in the NS5 region of ZIKV genome using sequences of ZIKV strains circulating in Africa and Asia. Indeed, isolates from Malaysia and the outbreak of Micronesia are closely related [30].

Real-time RT-PCR for the diagnosis of acute ZIKV infection has many advantages compared to virus isolation and conventional RT-PCR. Virus isolation is considered as the "gold standard" for diagnosis of viral infection [31]. However, it has the disadvantage of low sensitivity and needs more than 10 days. Compared to conventional RT-PCR, real-time RT-PCR has several advantages such as rapidity, low risk of false positive results, high sensitivity, specificity and the possibility of quantitative measurements.

The assay was tested on ZIKV isolates from various geographical locations (Senegal, Cote d'ivoire, Burkina Faso and Central African Republic), hosts (mosquito, human and monkey) covering a period of 36 years. Compared to the only available assay based on ZIKV samples
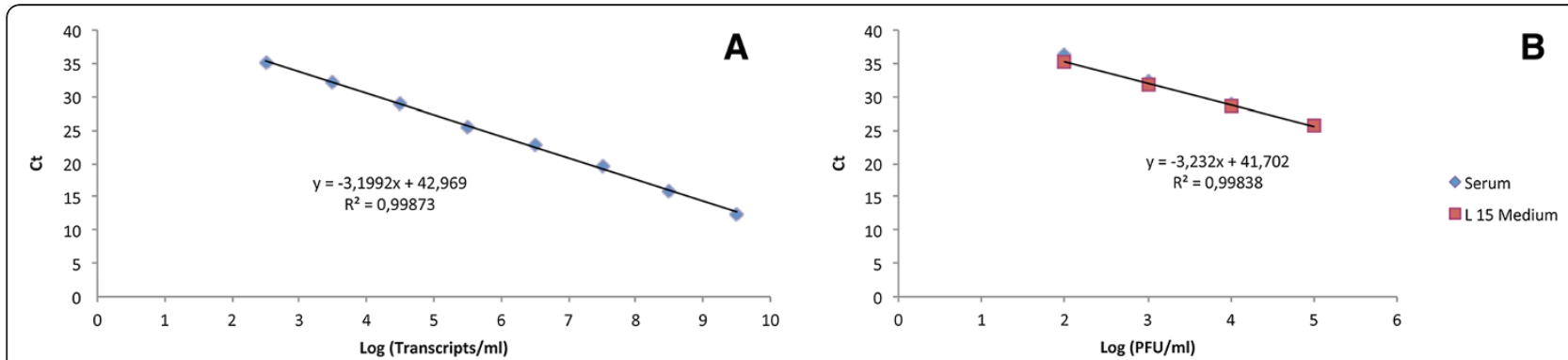

Figure 2 Sensitivity of the rRT-PCR assay. (A) Standard curve for Zika virus RNA transcript dilution series showing the threshold cycles Ct plotted against the $\log _{10}$ of Zika RNA transcripts and (B) Standard curve obtained with 10-fold serial dilutions of Zika virus. Ct values obtained are plotted against the log of the quantity of infectious virus (pfu/ml). 


\begin{tabular}{|c|c|c|}
\hline \multirow[t]{2}{*}{$\mathrm{PFU} / \mathrm{ml}$} & \multicolumn{2}{|c|}{$\mathrm{Ct}$} \\
\hline & serum & L15 medium \\
\hline 50000 & $25.60 \pm 1.138$ & $25.70 \pm 1.138$ \\
\hline 5000 & $28.88 \pm 1.443$ & $28.58 \pm 1.443$ \\
\hline 500 & $32.23 \pm 1.604$ & $31.92 \pm 1.604$ \\
\hline 50 & $36.24 \pm 1.61$ & $35.36 \pm 1.61$ \\
\hline 5 & ND & ND \\
\hline 0.5 & ND & ND \\
\hline
\end{tabular}

obtained during the outbreak in Micronesia, the advantage of our assay is that the primers and probe of our rRT-PCR assay were designed and evaluated using genetic diversity and geographic distribution of ZIKV isolated over 36 years. The developed rRT-PCR assay allowed the detection of $0.5 \mathrm{pfu} / \mathrm{ml}$. This detection limit value is similar to that found by Wu et al., [29] and is therefore sensitive enough to diagnose ZIKV in clinical cases. Indeed, viraemia found in human infection ranges from $10^{2}$ to $10^{6} \mathrm{pfu} / \mathrm{ml}[8,10,21,32]$. The limit of detection by testing 10 fold-dilutions normal human plasma and L-15 growth medium for AP61 cell was the same. ZIKV was detected up to dilution $50 \mathrm{pfu} / \mathrm{ml}$ both in normal human plasma. and L-15 medium. This finding suggests a high reproducibility of the ZIKV rRT-PCR assay. Moreover, the rRT-PCR assay established for ZIKV was found to be more sensitive than that of the traditional RT-PCR assay developed previously [33]. This result confirms the greater sensitivity of real-time PCR compared to conventional RT-PCR [34]. The reproducibility of the real time PCR assay was high as shown by intraand inter-assay variation analysis. The assay may improve early identification of acute Zika fever, and implementation of early treatment and control measures during ZIKV outbreaks. However, in this study, our assay was evaluated using synthetic normal human plasma. Then, further studies using humans sera naturally infected by ZIKV are needed to validate this assay.

For a better assessement of the established rRT-PCR, the specifity was tested with a variety of mosquito-borne and vertebrate-borne flaviviruses as described in Materials and methods. No cross reaction was observed demonstrating the high specificity this assay. The specificity of the rRT-PCR assay allows its use for differential diagnosis of arboviral infections in Africa and Asia where ZIKV co-circulates with other arboviruses such as Dengue, Chikungunya and yellow fever viruses [22].

Virus isolation has documented a permanent circulation of ZIKV in Southeastern Senegal since 1972 [2,13]. The TaqMan assay was able to detect ZIKV in fieldcollected mosquito pools at higher sensitivity than virus isolatiob in AP61 cells (Khi2 test, $\mathrm{p}=0.037$ ). However, 7 positive mosquitoes pool was found only by virus isolation and negative by rRT-PCR assay.

This might be explained by the loss of the ZIKV RNA during the extraction process or during freezing and thawing the samples prior to the rRT-PCR test. Furthermore, no mosquito pool was found positive for dengue and yellow fever, major abovirus which co-circulate with ZIKV in Kedougou aera. In addition, ZIKV NS5 region of the positive mosquito pools showed 97 to $100 \%$ identity with senegalese ZIKV strain ArD41519 (accession number HQ234501), confirming the specificity of the assay. It will therefore help to improve screening for ZIKV in mosquito pools.

Like others arbovirus (YFV, DENV, CHIKV) in this Kedougou region, ZIKV were found frequently at the end of the rainy season between September and December $[2,35]$, characterized by the existence of a very diversified mosquito fauna and an old population of vectors that have taken several blood meals and thus are more likely to be infected by contact with viremic hosts. ZIKV was also detected in mosquito vectors as collected in June, corresponding to the beginning of the rainy season and the mosquito activities in southern Senegal. These detections suggest a rapid and huge amplification of the virus in the vectors that might be infected through vertical transmission and/ or from vertebrate reservoirs [4].

\section{Conclusion}

The expansion of ZIKV outside Africa shows the need to develop rapid assays and specific monitoring of the virus. Rapid detection of the virus in field-collected specimens can accelerate appropriate mosquito control measures that could prevent transmission and disease among human population. In this study we developed a rapid, sensitive and specific real time PCR for the detection of ZIKV circulating in Africa and Asia. This assay will be a useful tool for differential Zika fever diagnostics in a situation where number of other disease like malaria, dengue, chikungunya co-circulate and are clinically indistinguishable.

\section{Competing interests}

The authors declare that they have no competing interests.

\section{Authors' contributions}

Oum F, Ous F, MD, MW and AAS designed the study, analyzed the data and wrote the manuscript. Oum F and DD performed the experiment. All the authors have read and approved the final manuscript.

\section{Acknowledgements}

The authors thank Lang Girault for providing ZIKV strains. This work was supported by Arbovirus Unit of Pasteur Institute in Dakar and the National Institutes of Health (NIH), Grant Number 5R01A1069145.

\section{Author details}

${ }^{1}$ Unité des Arbovirus et virus de fièvres hémorragiques, Institut Pasteur Dakar, 36, Avenue Pasteur, BP 220 Dakar, Senegal. ' Unité d'entomologie médicale 36, 
Avenue Pasteur, BP 220 Dakar, Senegal. ${ }^{3}$ Department of Virology, University Medical Center Göttingen, Göttingen, Germany.

Received: 24 June 2013 Accepted: 30 September 2013 Published: 22 October 2013

\section{References}

1. Kuno G, Chang GJJ, Tsuchiya KR, Karabatsos N, Cropp CB: Phylogeny of the genus flavivirus. J Virol 1998, 72(1):73-83.

2. Cornet M, Robin Y, Chateau R, Hème G, Adam C, Valade M, Le-Gonidec G, Jan C, Renaudet J, Dieng PL, Bangoura JF, Lorand A: Isolement d'arbovirus au Sénégal Oriental à partir de moustiques $(1972$ - 1977) et notes sur l'épidémiologie des virus transmis par les Aedes, en particulier du virus amaril. Cah ORSTOM ser Ent med et Parasitol 1979, XVII(3):149-163.

3. Savage HM, Fritz CL, Rutstein D, Yolwa A, Vorndam V, Gubler DJ: Epidemic of dengue-4 virus in Yap State, federated States of Micronesia, and implication of Aedes hensilli as an epidemic vector. Am J Trop Med Hyg 1998, 58:519-524.

4. Cornet M, Chateau R, Valade M, Dieng PL, Raymond H, Lorand A: Données bio-écologiques sur les vecteurs potentiels de virus amaril. Cah ORSTOM Ser Ent med et Parasitol 1978, 16:315-341.

5. Chambers TJ, Chang HS, Galler R, Rice CM: Flavivirus genome organization, expression and replication. Annu Rev Microbiol 1990, 44:649-688.

6. Lindenbach $B D$, Rice CM: Molecular biology of flaviviruses. Adv Virus Res 2003, 59:23-61.

7. Kuno G, Chang GJJ: Full-length sequencing and genomic characterization of Bagaza, Kedougou, and Zika viruses. Arch Virol 2007, 152:687-696.

8. Bearcroft WG: Zika virus infection experimentally induced in a human volunteer. Trans R Soc Trop Med Hyg 1956, 50(3):442-448.

9. MacNamara FN: Zika virus : a report on three cases of human infection during an epidemic of jaundice in Nigeria. Trans R Soc Trop Med Hyg 1954, 48(2):139-145.

10. Simpson DL: Zika virus infection in man. Trans R Soc Trop Med Hyg 1964, 58:335-338

11. Duffy MR, Chen T, Hancock WT, Power AM, Kool JL, Lanciotti RS, Pretrick M, Marfel M, Holzbauer S, Dubray C, Guillaumot L, Griggs A, Bel M, Lambert AJ, Laven J, Kosoy O, Panella A, Biggerstaff BJ, Fisher M, Hayes EB: Zika virus outbreak on Yap island, federation states of Micronesia. N Engl J Med 2009, 360:2536-2543.

12. Dick GW, Kitchen SF, Haddow AJ: Zika virus. I. Isolations and serological specificity. Trans R Soc Trop Med Hyg 1952, 46:509-520.

13. Hayes EB: Zika virus oitside Africa. Emerg Infect Dis 2009, 15(9):1347-1350.

14. Akoua-Koffi C, Diarrasouba S, Bénié VB, Nigbichi JM, Bozona T: Investigation autour d'un cas mortel de fièvre jaune en Côted'Ivoire en 1999. Bull Soc Pathol Exot 2001, 94(3):227-230.

15. Digoutte JP, Salaun JJ, Robin Y, Bres P, Cagnard VJM: Les arboviroses mineures en Afrique Centrale et Occidentale. Med Trop 1980, 40:5.

16. Fagbami AH: Zika virus infection in Nigeria: virological and seroepidemiological investigation in Oyo State. J Hyg Camb 1979, 83:213-219.

17. Marcchette NJ, Garcia R, Rudnick A: Isolation of Zika virus from Aedes aegypti :mosquitoes in Malayssia. Am J Trop Med Hyg 1969, 18(3):411-415.

18. McCrae AW, Kirya BG: Yellow fever and Zika virus epizootics and enzootics in Uganda. Trans R Soc Trop Med Hyg 1982, 76(4):552-562.

19. Robert V, Lhuillier M, Meunier D, Sarthou JL, Monteny N: Virus Amaril, dengue 2 et autres arbovirus isolés de moustiques, au Burkina Faso, de 1983 à 1986: considérations entomologiques et épidémiologiques. Bull Soc Pathol Exot 1986, 86:90-100.

20. Base de données sur les arbovirus africains: http://www.pasteur.fr/ recherche/banques/CRORA/.

21. Lanciotti RS, Kosoy OL, Laven JJ, Velez JO, Lambert AJ, Johnson AJ, Stanfield SM, Duffy MR: Genetic and serologic properties of Zika Virus associated with an epidemic, Yap State, Micronesia, 2007. Emerg Infect Dis 2008, 14(8):1232-1239.

22. Foy BD, Kobylinski KC, Foy JLC, Blitvich BJ, Travassos da Rosa A, Haddow AD, Lanciotti RS, Tesh RB: Probable non-vector-borne transmission of Zika virus, Colorado USA. Emerg Infect Dis 2011, 17:5.

23. Digoutte JP, Calvo-Wilson MA, Mondo M, Traoré-Lamizana M, Adam F: Continuous cell lines immune ascite fluid pools in arbovirus detection. Res Virol 1992, 143:417-422.
24. Thompson JD, Gibson TJ, Plewniak F, Jeanmougin F, Higgins DG: The ClustalX windows interface: flexibles strategies for multiple sequence alignment aided by quality analysis tools. Nucl Acids Res 1997, 24:4876-4882.

25. Tolstrup N, Nielsen PS, Kolberg JG, Frankel AM, Vissing H, Kauppinen S: Oligo Design: optimal design of LNA (locked nucleic acid) oligonucleotide capture probes for gene expression profiling. Nucl Acids Res 2003, 31:3758-3762.

26. Weidmann M, Muhlberger E, Hufert FT: Rapid detection protocol for filoviruses. J Clin Virol 2004, 30:94-99.

27. Diallo D, Sall AA, Buenemann M, Chen R, Faye O, Diagne CT, Ba Y, Dia I, Watts D, Weaver SC, Hanley KA, Diallo M: Landscape ecology of sylvatic chikungunya virus and mosquito vectors in southeastern senegal. PLOS Neg/ Trop Dis 2012, 6:e1649.

28. Weidmann M, Faye O, Faye O, Kranaster R, Marx A, Nunes MR, Vasconcelos PF, Hufert FT, Sall AA: Improved LNA probe-based assay for the detection of African and South American yellow fever virus strains. J Clin Virol 2010, 48(3):187-192.

29. Wu SJ, Pal S, Ekanayake S, Greenwald D, Lara S, Raviprakash K, Kochel T, Porter K, Hayes C, Nelson W, Callahan J: A dry-format field-deployable quantitative reverse transcriptase-polymerase chain reaction assay for diagnosis of dengue infections. Am J Trop Med Hyg 2008, 79(4):505-510.

30. Haddow A, Schuh AJ, Yasuda CY, Kasper MR, Heang V, Huy R, Guzman H, Tesh RB, Weaver SC: Genetic characterization of Zika virus strains: geographic expansion of the Asian lineage. PLoS Negl Trop Dis 2012, 6(2):1-7.

31. Leland DS, Ginocchio CC: Role of cell culture for virus detection in the age of technology. Clin Microbiol Rev 2007, 20(1):49-78.

32. Weinbren MP, Williams MC: Zika virus: further isolations in the Zika area, and some studies on the strains isolated. Trans R Soc Trop Med Hyg 1958 52(3):263-268.

33. Faye O, Faye O, Dupressoir A, Weidmann M, Ndiaye M, Sall AA: One Step RT-PCR method for detection of Zika virus. J Clin Virol 2008, 43(1):96-101.

34. Lanciotti RS, Kerst AJ, Nasci RS, Godsey MS, Mitchell CJ, Savage HM, Komar N, Panella NA, Allen BC, Volpe KE, Davis BS, Roehrig JT: Rapid detection of West Nile virus from human clinical specimens, field-collected mosquitoes, and Avian samples by a TaqMan reverse transcriptase-PCR assay. J Clin Microbiol 2000, 38(11):4066-4071.

35. Monlun E, Zeller H, Le-Guenno B, Traoré-Lamizana M, Hervy JP, Adam F, Ferrara L, Fontenille D, Sylla R, Mondo M, Digoutte JP: Surveillance de la circulation des arbovirus d'intérêt médical dans la région du Sénégal Oriental (1988-1991). Bull Soc Pathol Exot 1993, 86:21-28.

doi:10.1186/1743-422X-10-311

Cite this article as: Faye et al:: Quantitative real-time PCR detection of Zika virus and evaluation with field-caught Mosquitoes. Virology Journal 2013 10:311.

\section{Submit your next manuscript to BioMed Central and take full advantage of:}

- Convenient online submission

- Thorough peer review

- No space constraints or color figure charges

- Immediate publication on acceptance

- Inclusion in PubMed, CAS, Scopus and Google Scholar

- Research which is freely available for redistribution

Submit your manuscript at www.biomedcentral.com/submit
C Biomed Central 